\title{
Wnt/Beta-Catenin/Tcf Signaling: A Critical Pathway in Gastrointestinal Tumorigenesis
}

\author{
Frank T. Kolligs Guido Bommer Burkhard Göke \\ Medizinische Klinik II, Klinikum Grosshadern der Universität München, Deutschland
}

\section{Key Words}

Adenomatous polyposis coli $\cdot$ Wnt $\cdot \beta$-Catenin $\cdot$ T-cell factor . Colorectal cancer. Gastrointestinal cancer

\begin{abstract}
Cancers of the gastrointestinal tract, including the liver, bile ducts, and pancreas, constitute the largest group of malignant tumors. Colorectal cancer is one of the most common neoplastic diseases in Western countries and one of the leading causes of cancer-related deaths. Inactivation of the adenomatous polyposis coli (APC) tumorsuppressor gene during early adenoma formation is thought to be the first genetic event in the process of colorectal carcinogenesis followed by mutations in oncogenes like K-Ras and tumor-suppressor genes like p53. Identification of the interaction of APC with the protooncogene $\beta$-catenin has linked colorectal carcinogenesis to the Wnt-signal transduction pathway. The main function of APC is thought to be the regulation of free $\beta$-catenin in concert with the glycogen synthase kinase $3 \beta$

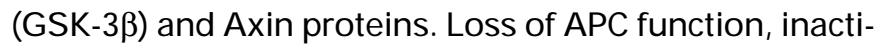
vation of Axin or activating $\beta$-catenin mutations result in the cellular accumulation of $\beta$-catenin. Upon translocation to the nucleus $\beta$-catenin serves as an activator of Tcell factor (Tcf)-dependent transcription leading to an increased expression of several specific target genes including c-Myc, cyclin D1, MMP-7, and ITF-2. While APC mutations are almost exclusively found in colorectal
\end{abstract}

cancers, deregulation of $\mathrm{Wnt} / \mathrm{\beta}$-catenin/Tcf signaling is also common in other gastrointestinal and extra-gastrointestinal human cancers. In a fraction of hepatocellular carcinomas the Wnt pathway is deregulated by inactivation of Axin or stabilizing mutations of $\beta$-catenin. The majority of hepatoblastomas and a group of gastric cancers also carry $\beta$-catenin mutations. Clearly, this pathway harbors great potential for future applications in cancer diagnostics, staging, and therapy.

Copyright $\odot 2002$ S. Karger AG, Basel

\section{Introduction}

The Wnt pathway plays key roles in development, tissue homeostasis, and cancer [1-5]. It was originally described in Drosophila as Wingless pathway and is highly conserved among flies, frogs, and mammals. The combined effort of genetic, biochemical and developmental research has led to the comprehensive understanding of the Wnt pathway as it is known today. The most extensively studied part of this pathway leads to transcriptional activation of specific genes and is referred to as the canonical Wnt pathway (fig. 1): Extracellular Wnt proteins bind to and activate membrane-bound Frizzled receptors which in turn mediate phosphorylation of Dishevelled. Through binding to Axin Dishevelled inhibits phosphorylation of $\beta$-catenin by disrupting a complex consisting of the adenomatous polyposis coli (APC), Axin, and glyco-

\section{KARGER \\ Fax +41613061234 \\ E-Mail karger@karger.ch \\ www. karger.com \\ (C) 2002 S. Karger AG, Basel \\ 0012-2823/02/0663-0131\$18.50/0 \\ Accessible online at: www. karger.com/dig}

Dr. Frank T. Kolligs

Medizinische Klinik II, Klinikum Grosshadern der Universität München

Marchioninistrasse 15, D-81377 Munich (Germany)

Tel. +49 897095 0, Fax +498970956183

E-Mail fkolligs@med2.med.uni-muenchen.de 


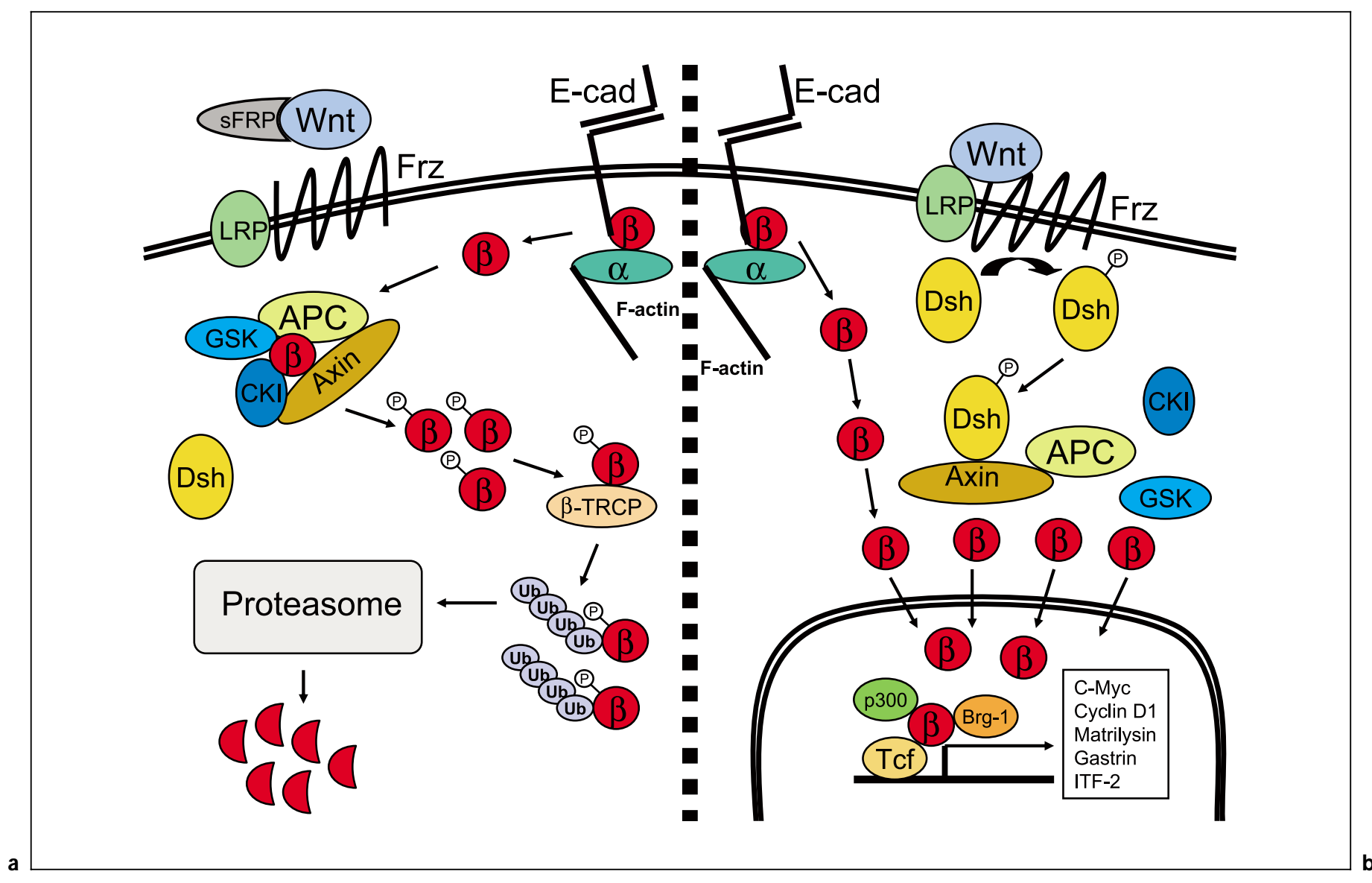

Fig. 1. Wnt-signaling and regulation of free $\beta$-catenin. a Under physiological conditions the largest fraction of $\beta$-catenin $(\beta)$ is bound to the cell-cell adhesion molecule E-cadherin (E-cad). Thereby it links the cell membrane via $\alpha$-catenin $(\alpha)$ to the actin cytoskeleton. After priming phosphorylation by $\mathrm{CKI}$, free $\beta$-catenin is bound by the APC/Axin/GSK complex and phosphorylated amino terminally. Phosphorylated $\beta$-catenin binds to the F-box protein $\beta$ - TrCP and, after ubiquitination (Ub), is degraded by the proteasome. b Binding of Wnt ligands to a serpentine Frizzled receptor (Frz) results in phos- phorylation of Dishevelled (Dsh). Upon binding to Axin the APC/ Axin/GSK-complex dissociates and $\beta$-catenin bypasses the destruction machinery. After translocation to the nucleus $\beta$-catenin binds to $\mathrm{T}$-cell factors (Tcf) and recruits the chromatin-remodeling proteins p300 and Brg-1 to responsive promoters, thereby activating the transcription of specific target genes, including c-Myc, cyclin D1, matrilysin, gastrin, and ITF-2. Soluble Frizzled-related proteins (sFRP) bind to Wnt factors and exert a Wnt-antagonistic effect. gen synthase kinase $3 \beta$ (GSK-3 $\beta$ ) proteins. Unphosphorylated $\beta$-catenin then binds to transcription factors of the T-cell factor/lymphoid-enhancer factor (Tcf/Lef) family and activates the transcription of specific target genes including c-Myc, cyclin D1, MMP7, gastrin and ITF-2 [611]. However, binding of some Wnt factors to certain Frizzled receptors can also result in $\mathrm{Ca}^{2+}$ release and protein kinase $\mathrm{C}$ activation, which does not lead to activation of $\beta$-catenin/Tcf signaling. In contrast to the canonical Wnt pathway this signal transduction cascade has been named the $\mathrm{Wnt} / \mathrm{Ca}^{2+}$ pathway [12].

$70-80 \%$ of colorectal cancers have defects in the Wnt pathway $[13,14]$. Most frequently APC mutations are found, but a subset of tumors wild-type for APC carry $\beta$ catenin mutations. The current model of colorectal carcinogenesis predicts that at least four mutations in critical genes are required for the evolution of colorectal cancer $[15,16]$. The earliest adenomatous stages are associated with inactivating APC mutations, followed by mutations of the oncogene K-Ras and inactivation of tumor-suppressor genes including p53. Roughly $20-30 \%$ of hepatocellular carcinomas (HCCs) carry mutations in the Axin or the $\beta$-catenin gene [5] also resulting in deregulation of Wnt signaling. The epidemiological importance of cancers associated with defects in the Wnt pathway is evident. Colorectal cancer is one of the leading causes of can- 
cer-related morbidity and mortality in Western countries. In Europe alone more than 210,000 new cases and 110,000 deaths are reported each year [17] and the risk of developing colorectal cancer during a lifetime is about 5$6 \%$. While colorectal cancer is much more common in developed than in developing countries, HCC is the most frequent cancer in some regions of the world [17].

\section{Components of the Wnt Pathway and Their Contribution to Gastrointestinal Tumors}

\section{The First Steps in the Wnt-Signaling Cascade: \\ Wnt Factors, Frizzled Receptors and Dishevelled}

Wnt proteins constitute a large family of at least 16 secreted cysteine-rich glycoproteins, some of which have been shown to promote neoplastic transformation in animal models and tissue culture systems [18]. However, in contrast to down-stream components of the pathway, their direct involvement in human carcinogenesis has never been demonstrated. Wnt proteins bind to the extracellular domain of the Frizzled family of seven transmembrane receptors. So far more than 11 different Frizzled genes have been identified in vertebrates, but little is known about their specific functions and ligand specificities. Recently, the low-density lipoprotein receptor-related proteins, LRP5 and LRP6, have been found to act as co-receptors for Wnt signal transduction [19-21]. In addition to membrane-bound Frizzled receptors, a group of secreted Frizzled-related proteins has been described. Through binding of Wnt proteins they seem to exert an antagonistic effect on Wnt signaling [22-24]. However, some of the Frizzled-related proteins also seem to bind to classical membrane-bound Frizzled receptors [25] and some even seem to activate Wnt signaling [26]. Whether Frizzled receptors or Frizzled-related proteins directly contribute to carcinogenesis is not clear yet, but it has been reported that the Frizzled receptor E3 (FzE3) is expressed in many esophageal cancers but not in matched normal tissues [27]. Interestingly, this expression of FzE3 correlates with nuclear translocation of $\beta$-catenin.

Binding of a Wnt ligand to a member of the Frizzled receptor family results in its activation. Activated Frizzled receptors recruit the cytoplasmic protein Dishevelled to the inner cell membrane and mediate its phosphorylation [28-31]. It is unknown, whether Dishevelled directly binds to Frizzled receptors or whether its binding is mediated through other so far unknown proteins. To date, two main functions of Dishevelled have been identified. Through distinct domains Dishevelled transduces Wnt signals [32] and activates the jun-N terminal kinase (JNK) pathway [33-35]. Wnt signals are transduced by direct binding of Dishevelled to Axin [30, 36]. This results in the inhibition of GSK-3 $\beta$-dependent phosphorylation of $\beta$ catenin. Most likely this occurs through disintegration of the APC/Axin/GSK-3 $\beta$ complex [36]. In addition, protein kinase CK2 (casein kinase II), a protein serine/threonine kinase, is also able to phosphorylate Dishevelled independent of Frizzled [37, 38]. How far Dishevelled and CK2 directly promote neoplastic transformation via $\beta$-catenin/ Tcf is unknown. So far no mutations of these proteins have been reported in human cancers.

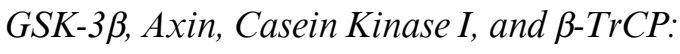

\section{Regulators of $\beta$-Catenin}

Tight regulation of the free cytoplasmic pool of $\beta$-catenin is the central switch of the Wnt pathway. The current view predicts that in the absence of a Wnt-signal degradation of $\beta$-catenin is initiated by priming phosphorylation of serine residue 45 (S45) by casein kinase I (CKI) [39, 40]. Phosphorylation of S45 is dependent on binding of CKI to axin [40]. The next step involves a multi-protein complex consisting of $\beta$-catenin, APC, Axin, and the serine/threonine kinase GSK-3 $\beta$ [13]. In this complex GSK3 facilitates further phosphorylation of $\beta$-catenin's amino terminus: starting at threonine 41 , and walking downstream to S37 and S33. The aim of this cascade is the generation of the canonical $\beta$-TrCP recognition site around S33/S37 (DS*GXXS*; $\mathrm{S}^{*}=$ phosphoserine; fig. 2c) [41]. Then $\beta$-catenin isoforms phosphorylated at all four critical serine/threonine residues are bound by the F-box protein $\beta$-TrCP [42-44], a subunit of the SCF-type E3 ubiquitin ligase complex [45]. This complex facilitates ubiquitination and subsequent proteasome degradation of phosphorylated $\beta$-catenin [46]. The finding that priming phosphorylation of S45 is required for further phosphorylation by GSK-3 $\beta$ solves the longstanding mystery why mutation of one of the four serine and threonine residues is sufficient for inhibition of $\beta$-catenin degradation: mutation of one single of the four phosphorylation targets inhibits further downstream phosphorylation. And phosphorylation of serines 33 and 37 is required for binding of $\beta$-catenin to $\beta$-TrCP. In addition to mutations of the aforementioned serine and threonine residues, mutations of asparagin 32 or glycin 34, which are also common in human cancers [5], likewise destroy the $\beta$ - TrCP recognition motif site, resulting in stabilization of $\beta$-catenin. In contrast, mutation of serines 25 and 29 does not affect the stability of $\beta$-catenin since both residues are located amino terminally to the $\beta$-TrCP-binding region. The signifi- 

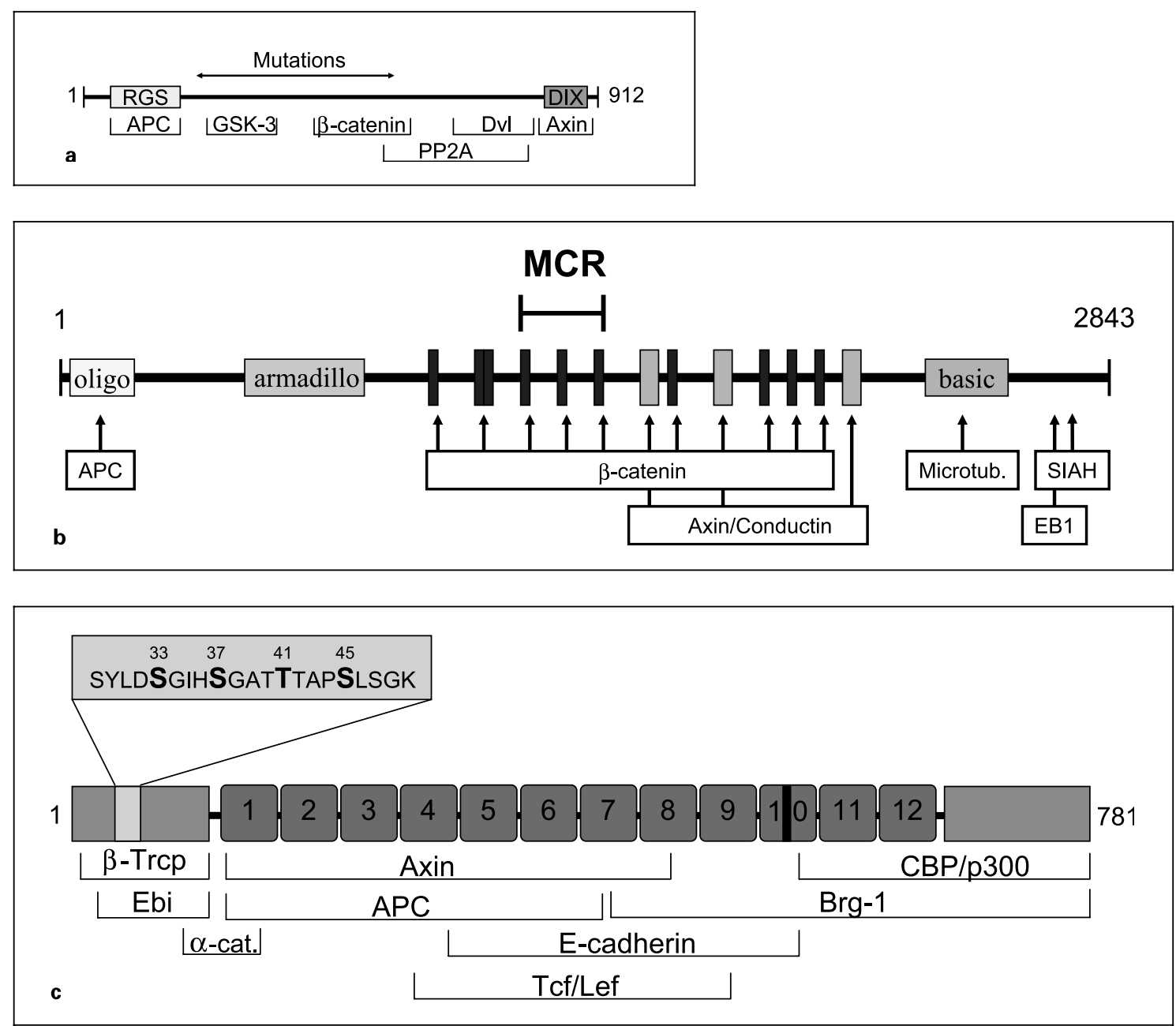

Fig. 2. Components of the Wnt pathway found to be mutated in gastrointestinal cancers. a Mutation of Axin-1 in hepatocellular carcinoma results in loss of regions responsible for binding to GSK-3 and $\beta$-catenin. b APC forms homodimers with itself by the oligomerization domain (oligo). The armadillo repeat region is made up of a 42amino acid motif that is repeated 13 times. The regions for binding and downregulation of $\beta$-catenin and the binding region of Axin/conductin partly overlap. Microtubules bind to the basic region (basic) and the binding regions of Siah-1 and EB1 are confined to the carboxy terminus. The mutation cluster region (MCR) is located amino terminal to the Axin/conductin-binding sites. Most mutant APC proteins can no longer bind to Axin and are therefore incapable of downregulating $\beta$-catenin. $\mathbf{c}$ The amino and carboxy termini of $\beta$-catenin serve as transcriptional activators. The central part is made up of 12 highly homologous armadillo repeats (boxes 1-12) which mediate most interactions with other proteins. Serine and threonine residues 33,37 and 41 (insert) are the GSK-3 phosphorylation sites. Serine 45 is the target of priming phosphorylation by CKI. Mutation of one of these residues prevents degradation of $\beta$-catenin.

allowing assembly of the APC/Axin/GSK-3 $\beta / \beta$-catenin complex [52]. Interaction of Axin proteins with APC, GSK-3 $\beta$, and Axin as well as with Dishevelled occurs by non-overlapping regions. Binding to APC is facilitated through the RGS domain [53, 54] and binding to Dishevelled occurs through a domain called DIX which is similar to a region also found in Dishevelled [30, 55] (fig. 2a). Based on its function to downregulate oncogenic Wnt signaling Axin could be viewed as a tumor-suppressor gene. 
In fact, this view is supported by several findings. In a subset of HCCs Axin is biallelically mutated leading to Axin proteins lacking the $\beta$-catenin-binding site [56]. And in 11 of 45 colorectal cancers with defective DNA mismatch repair, lacking mutations in both $\beta$-catenin and APC, the Axin-2 gene was found to be mutated [57]. Interestingly, Axin-2 was just recently identified to be a target gene of $\beta$-catenin/Tcf signaling (see below).

Due to their central function as regulators of $\beta$-catenin, generally all proteins of the APC/Axin/GSK-3 $\beta$ complex would qualify as tumor suppressor genes. But, however, in contrast to APC and Axin, so far no mutations or deletions in the GSK-3 $\beta$ gene have been reported [58]. This might be explained by the fact that GSK-3 $\beta$ also phosphorylates other key regulatory proteins outside the Wnt pathway, such as proteins in insulin and growth factor signaling pathways [59]. Direct inhibition of GSK-3 $\beta$ function with the consequence of cellular accumulation of $\beta$ catenin has also been reported for the proteins Frat-1 [60], $\mathrm{Akt} /$ protein kinase $\mathrm{B}$ (PKB) [61], the $\beta \mathrm{II}$ isoform of protein kinase $\mathrm{C}$ (PKC- $\beta \mathrm{II})$ [62], and polycystin-1 [63]. The proto-oncogene Akt/PKB is an extensively studied downstream target of insulin-like growth factor, integrin-linked kinase, and PI3-kinase signaling [64, 65]. Involvement of $\mathrm{Akt} / \mathrm{PKB}$ in gastrointestinal carcinogenesis seems likely since insulin-like growth factor receptor has been found to be overexpressed in colorectal cancers [66]. PKC- $\beta$ II has also been shown to be upregulated in colorectal cancer [67] and intracellular PKC- $\beta$ II levels are increased after exposure to secondary bile acids, which are thought to be carcinogenic to the colonic epithelium [68].

\section{APC: Gatekeeper of Colorectal Tumorigenesis}

The APC gene was identified on chromosome $5 \mathrm{q}$ by genetic analysis of familial adenomatous polyposis (FAP) families [69-71]. In their early adulthood patients with FAP develop multiple adenomatous polyps of the colorectal epithelium, some of which progress to invasive carcinomas. Some FAP patients also suffer from extracolonic tumors, such as desmoid tumors, ampullary carcinomas, and hepatoblastomas $[72,73]$. The sequence of the APC gene spans 15 exons and encodes a 2,843-amino acid protein of $310 \mathrm{kD}$. Subsequent studies defined the critical role of APC in the genesis of inherited and sporadic colorectal cancer and its main function as a regulator of free $\beta$-catenin [74-76]. While germline inactivation of APC mutations occurs throughout the entire gene, somatic mutations are clustered at the $5^{\prime}$ end of exon 15 between codons 1280 and 1500 (mutation cluster region, MCR; fig. 2b) [77] resulting in a frame shift or a premature stop codon and a truncated APC protein. Biallelic inactivation of APC usually results from a truncating mutation coupled with a deletion of the long arm of chromosome 5 [72]. Altogether, in 70-80\% of all colorectal cancers APC function is inactivated by loss of APC expression or expression of a truncated protein [72].

The APC protein consists of multiple functional domains that mediate oligomerization and interaction with many cellular proteins including $\beta$-catenin [76, 78], $\gamma$ catenin [79-81], GSK-3 $\beta$ [49], Axin/conductin [51-53], tubulin [82, 83], EB1 [84], hDLG [85], Asef [86], and Siah-1 [87, 88]. However, the main function of APC seems to be the regulation of the free non-membranebound pool of $\beta$-catenin in concert with GSK-3 $\beta$ and the scaffold protein Axin/conductin. Truncated APC proteins loose their ability to bind to Axin which results in the inability to downregulate $\beta$-catenin, which then in turn accumulates in the cytoplasm and the nucleus [54, 89]. However, it has recently been shown that APC is also involved in the downregulation of non-phosphorylated, oncogenic forms of $\beta$-catenin which escape the aforementioned $\beta$-TrCP-dependent destruction $[87,88]$. For this alternative pathway of destruction a different F-box protein, Ebi, is recruited. This alternative pathway requires the interaction of APC with Siah-1, a p53-inducible gene, which is also involved in the regulation of the tumor-suppressor gene, DCC [90]. As Siah-1 binds to the carboxy terminus of APC and most colorectal cancers carry truncating mutations lacking the carboxy terminus, both the Axin/GSK-3 $\beta / \beta$-TrCP and the Siah-1/Ebi destruction pathways are abrogated. Consequently, only in tumors carrying $\beta$-catenin mutations and expressing wild-type APC, the Siah-1/Ebi system can have a functional role in regulating $\beta$-catenin.

As loss of APC function and oncogenic activation of $\beta$-catenin seem to be equally potent in terms of Tcf-transcriptional activation [91], it is surprising that APC mutations are found in the vast majority of colorectal cancers, whereas $\beta$-catenin mutations are only found in a subset of colorectal cancers wild-type for APC [58, 92-96]. This is particularly curious in light of the fact that both APC alleles need to be mutated versus only one $\beta$-catenin allele in order to deregulate Tcf signaling. One hypothesis to account for the highly discordant frequencies of APC and $\beta$-catenin mutations is that APC loss may provide the cell with a stronger growth advantage than activation of $\beta$ catenin, implying that APC has other vital functions besides promoting $\beta$-catenin degradation. Interestingly, $\beta$ catenin mutations are more frequent in small than in invasive adenomas, and tumors carrying mutated $\beta$-cate- 
nin are less aggressive than tumors showing loss of APC [96]. Of note, biallelic inactivation of APC outside colorectal tumors has only been reported for desmoid tumors [97]. These benign soft tissue tumors occur with an increased incidence in FAP patients. Up to $50 \%$ of sporadic desmoid tumors which are wild-type for APC carry $\beta$-catenin mutations $[98,99]$.

In addition to regulation of free $\beta$-catenin, APC has also been shown to have Wnt-independent functions mediated through its carboxy terminus, the region commonly lost in colorectal cancer. APC directly associates with the microtubule cytoskeleton and binds to microtubuleassociated proteins of the EB/RP family [82-84, 100, 101]. Most recently APC has also been suggested to be involved in the maintenance of chromosomal stability through localization to the kinetochore of metaphase chromosomes, a function most likely dependent on the interaction with EB1 [14, 102, 103].

\section{$\beta$-Catenin: Central Oncogene of the Wnt Pathway}

$\beta$-Catenin and its close relative $\gamma$-catenin are the vertebrate homologs of the Drosophila gene armadillo [104, 105]. $\beta$-Catenin was first identified because of its binding to the cytoplasmic domain of the cell-cell adhesion protein E-cadherin [106, 107]. Under physiological conditions most cellular $\beta$-catenin is bound to E-cadherin, a process regulated by tyrosine kinases and tyrosine phosphatases [108]. Promotion of tyrosine phosphorylation of $\beta$-catenin by treatment of cells with epidermal growth factor or hepatocyte growth factor $[109,110]$ leads to its dissociation from the adherens junctions and to its transfer to the cytosol. Whether the phosphorylation is performed by the growth factor receptors themselves or by soluble tyrosine kinases is unknown. However, it has been shown in vitro that the hepatocyte growth factor receptor c-Met and the epidermal growth factor receptor c-erbB-2 bind to $\beta$-catenin $[111,112]$. As described above, in the absence of a Wnt signal free $\beta$-catenin is then subsequently phosphorylated and degraded.

More recently, $\beta$-catenin has been implicated in human cancer [113] and its oncogenic potential has been extensively studied in in vitro tissue culture models [114, 115] and in vivo animal models [116-119]. Three separate mechanisms have been found to lead to accumulation of $\beta$-catenin in the cytoplasm and nucleus of cancer cells: inactivation of the APC tumor suppressor gene in colorectal cancer; Axin mutations in subsets of hepatocellular and colorectal cancers [56, 57], and mutations of $\beta$-catenin's amino terminus in a variety of cancers (fig. 2c, 3 ). In as many as $50 \%$ of colon tumors with intact APC gain- of-function mutations in the $\beta$-catenin gene have been identified [58, 91-94]. The highest frequencies of $\beta$-catenin mutations in colorectal tumors have been found in the presence of microsatellite instability [94, 120]. It is important to note that inactivating of APC mutations and activating of $\beta$-catenin mutations never seem to coexist in a tumor.

Besides colorectal cancers, liver malignancies are the gastrointestinal tumors with the second highest incidence of mutations in the Wnt pathway. Hepatoblastoma, the most common primary malignant liver neoplasm in childhood, occurring more frequently in FAP patients than in the general population, is probably the human tumor harboring the highest rate of $\beta$-catenin mutations with reported frequencies ranging from 52 up to $89 \%$ [121-123]. In HCC Wnt signaling can be activated through either $\beta$ catenin [124-127] or Axin mutations [56]. The rate of $\beta$ catenin mutations in $\mathrm{HCC}$ has been reported to be about $20 \%$ and higher. In HCCs associated with hepatitis C the rate of $\beta$-catenin mutations may even exceed $40 \%$ [128].

In esophageal cancers so far no $\beta$-catenin, APC or Axin mutations have been reported [129, 130]. But, as mentioned above, overexpression of FzE3 in squamous cell esophageal cancers correlates with nuclear translocation of $\beta$-catenin [27]. Nuclear accumulation of $\beta$-catenin has also been observed in Barrett's esophagus, a precursor of adenocarcinoma of the distal esophagus [131-133], suggesting an involvement of Wnt signaling in the genesis of both adenocarcinomas and squamous cell carcinomas of the esophagus. In intestinal-type gastric cancer $\beta$-catenin mutations have been reported to occur in 7 of 26 cases analyzed, but no $\beta$-catenin mutations were found in diffuse-type gastric cancer [134]. In 29 of 45 sporadic fundic gland polyps activating $\beta$-catenin mutations have been reported, whereas fundic gland polyps associated with FAP harbor germline APC mutations [135].

$\beta$-Catenin seems to play a minor role in the genesis of tumors of the pancreas, gallbladder, and biliary tract. So far no mutations of the $\beta$-catenin gene have been reported in pancreatic ductal cancer [136, 137], except for two mutations in pancreatic cancer cell lines [136]. However, just recently it was reported that three rare entities of pancreatic neoplasms, pancreatoblastomas, acinar cell carcinomas, and solid pseudopapillary tumors, frequently carry mutations in the $\beta$-catenin or APC genes [138-140]. In gallbladder adenomas $\beta$-catenin mutations have been described in about $60 \%$ of the cases analyzed, but interestingly $\beta$-catenin mutations are rare or absent in carcinomas or dysplasias of the gallbladder $[141,142]$. No $\beta$-catenin mutations have been reported for intrahepatic cholangio- 

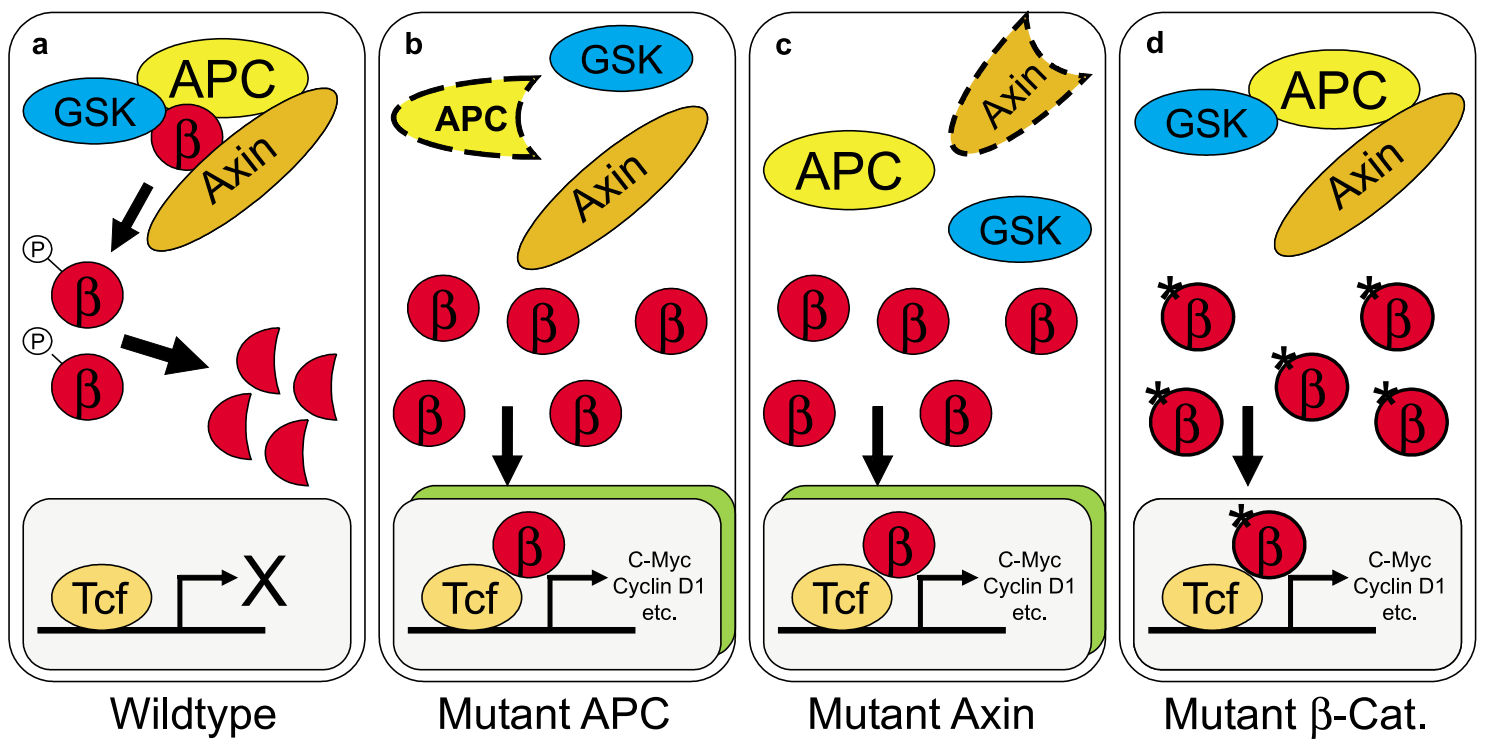

Fig. 3. Deregulation of Wnt signaling in gastrointestinal tumors. a Under physiological conditions free $\beta$-catenin ( $\beta$ ) is rapidly degraded. Three different mechanisms can lead to deregulation of Wnt/ $\beta$-catenin/Tcf signaling. Inactivation of the tumor suppressor APC (b) or the scaffold protein Axin (c), and activating mutations of $\beta$-catenin itself (d) result in cellular accumulation of $\beta$-catenin. After nuclear translocation and binding to Tcf, transcription of specific target genes is activated.

carcinoma [143]. In a study on biliary tract cancers only 8 of 107 cases had a $\beta$-catenin mutation [144].

In addition to gastrointestinal tumors, $\beta$-catenin mutations also occur with varying frequencies in gynecological tumors such as endometrial carcinoma [94, 145] and endometrioid ovarian carcinoma [146-148], in neoplasias of the skin such as melanoma [149] and pilomatricoma (with $75 \%$ of tumors harboring $\beta$-catenin mutations) [119], anaplastic thyroid carcinoma [150], prostate cancer [151], Wilms' tumor [152], lung cancer [153], and medulloblastoma [154].

$\gamma$-Catenin is structurally and functionally a close relative of $\beta$-catenin. Both proteins bind to E-cadherin in adherens junctions, but only $\gamma$-catenin is also present in desmosomes [155]. Like $\beta$-catenin, $\gamma$-catenin also binds to APC [81, 156], Axin/conductin [157], and Tcf/Lef factors [158], carries a carboxy terminal transcriptional activation domain [159, 160], is regulated by APC [160], and its deregulated expression results in neoplastic transformation [160]. However, so far no $\gamma$-catenin mutations have been described in human cancers, except in one gastric cancer cell line [136].

Wnt Signaling and Gastrointestinal Tumorigenesis

\section{The Final Step in Wnt Signaling: Activation of}

Tcf-Dependent Transcription

Cytosolic accumulation of $\beta$-catenin leads to the formation of complexes with Tcf/Lef transcription factors $[161,162]$. After nuclear translocation of these complexes, Tcf/Lef factors facilitate gene-specific DNA binding while $\beta$-catenin serves as transcriptional activator. The histone acetyltransferases p300/CBP have been found to serve as transcriptional coactivators of Tcf/Lef target gene expression through interaction with $\beta$-catenin [163-165]. Moreover, Brg-1, a component of the mammalian SWI/SNF chromatin-remodelling complex, was also found to be indispensable for $\beta$-catenin/Tcf-target gene expression [166]. By binding of $\mathrm{p} 300 / \mathrm{CBP}$ and $\mathrm{Brg}-1$ to $\beta$-catenin's carboxy terminus, the chromatin of regulatory regions of specific target gene promoters is remodeled facilitating the binding of the transcriptional machinery. The TATA-binding protein, Pontin52, is thought to mediate the contact between the $\beta$-catenin/Tcf- 4 complex and the basal transcriptional machinery [167].

Of all Tcf isoforms Tcf-4 is the only Tcf protein being consistently expressed in colorectal epithelial cells [168]. Tcf- 4 itself has been reported to carry mutations in a sub- 
set of colorectal cancers [169-171]. But, as all of these primary cancers and cancer cell lines also carry either inactivating APC or activating $\beta$-catenin mutations, these mutations of the Tcf-4 gene are not thought to substitute for APC or $\beta$-catenin mutations. A subset of the mutations affects the carboxy terminal region of Tcf-4 required for binding to CtBP, a member of the Groucho family of transcriptional repressors [172]. These repressors bind to Tcf4 in the absence of $\beta$-catenin and hereby tightly control Tcf-4 activity $[173,174]$. Therefore, Tcf-4 mutations are thought to have an additive rather than an initiating effect on neoplastic transformation. Once transformation of the colorectal epithelium has occurred, expression of Lef-1, a close homolog of Tcf-4, is upregulated. Only expression of the $\beta$-catenin-sensitive isoform of Lef- 1 is upregulated and can support the activation of Tcf/Lef target genes [175].

Several $\beta$-catenin/Tcf target genes are supposed to contribute to tumor initiation and progression in mice and humans. Identification of c-Myc and cyclin D1 as $\beta$-catenin-regulated genes solved several longstanding puzzles. c-Myc is a proto-oncogene that has long been known to be overexpressed at the mRNA and protein levels in colorectal tumors [176-180]. But, however, the reason for c-Myc overexpression in colon tumors remained unknown. Unlike many other tumors c-Myc gene rearrangements or amplifications are rare in colon tumors [181]. The identification of c-Myc as a Tcf-4 target gene linked deregulated expression of the proto-oncogene c-Myc to APC and $\beta$ catenin [6]. Unlike in most other human tumor types, genetic alterations in the p16INK4a growth-inhibitory pathway, which includes $\mathrm{Rb}, \mathrm{cdk} 4$, and cyclin $\mathrm{D} 1$, were only rarely found in colon tumors [182-185]. The discovery of cyclin D1 as a target of the $\beta$-catenin/Tcf pathway also linked this pathway to colorectal carcinogenesis [7, 8].

Matrilysin/MMP-7 is another target gene with supposedly critical functions in cancer promotion $[9,186]$. In the absence of the metalloproteinase MMP-7, intestinal tumorigenesis is strongly suppressed in APC mutant mice [187]. WISP-1 is a $\beta$-catenin/Tcf- 4 target gene belonging to the CCN family of growth factors [188] and cells overexpressing WISP-1 reveal characteristics of transformed cells including induction of tumor growth in nude mice. Deregulated expression of the Tcf target gene gastrin in $\mathrm{APC}^{-/+}$mice leads to an increase in polyp number, while gastrin-deficient $\mathrm{APC}^{-/+}$mice exhibit a reduction in intestinal polyp formation [10]. The basic helix-loop-helix transcription factor ITF-2 is expressed in two different splice variants ITF-2A and ITF-2B. The expression of the longer protein ITF-2B was found to be directly regulated by $\beta$-catenin/Tcf and, when overexpressed, to induce transformation of epithelial cells [11].

Tcf-1 [189] and Axin-2/conductin [190-193] have been identified as $\beta$-catenin/Tcf-4-regulated genes which negatively regulate $\mathrm{Tcf}$ signaling. Certain splice forms of Tcf- 1 act as naturally occurring dominant-negative Tcf/ Lefs which directly interfere with transcription of $\beta$-cate$\mathrm{nin} / \mathrm{Tcf}$-target genes by specifically binding to Tcf sites in gene-regulatory regions. These proteins lack the amino terminal-binding domain for $\beta$-catenin, but still bind to DNA. The access for functional $\beta$-catenin/Tcf complexes to responsive promoters is therefore blocked. In vivo studies have found that mutational inactivation of Tcf-1 leads to formation of multiple adenomas in the organs of mice including the gut. Loss of Tcf-1 expression in mice heterozygous for APC enhances the growth of intestinal adenomas. Tcf-1 therefore seems to exert a tumor-suppressive function [172]. Axin-2/conductin, but not the homologous protein Axin, is induced by $\beta$-catenin. Via a negative feedback loop activated $\beta$-catenin/Tcf-4 signaling is downregulated by targeting $\beta$-catenin for degradation. Other genes proposed as targets of $\beta$-catenin/Tcf include the gap junction protein connexin 43 [194], the inhibitory basic helix-loop-helix factor Id2 [195], peroxisome proliferator-activated receptor- $\delta$ [196], survivin [197], as well as the genes c-jun, fra-1, uPAR, ZO-1 [198], NBL-4 [199], DRCTNNB1A [200], MDR1 [201], and brachyury [202].

\section{Clinical Implications of Basic Research}

Much interest focuses on the Wnt/APC/catenin/Tcf signal-transduction cascade. So far this research has yielded little clinical impact. However, based on the knowledge that most APC gene mutations result in a truncated protein, a so-called protein truncation test has been developed $[203,204]$. This test, based on the in vitro transcription and translation of genomic PCR products of the APC gene, is used to prescreen FAP patients and their family members at risk. In case of a truncating mutation the detected protein is smaller in size than the corresponding wild-type product. By direct sequencing of the mutated DNA fragment APC mutations can be verified. As deaths from colorectal cancer can be avoided by early detection of colorectal adenomas and localized tumor stages much work has been invested into the development of DNA-based stool tests. Based on the large proportion of colorectal cancers with deregulation of Wnt signaling and 
the involvement of loss of APC function in very early steps of colorectal carcinogenesis, recently two molecular approaches to screen for colorectal cancer have been presented $[205,206]$. In both studies APC mutations were reliably detected by either DNA sequencing or a digital protein truncation test. Future studies will have to show how useful these tests finally are to screen for colorectal cancer. But searching for APC mutations only will probably not be sufficient as the only marker indicating a colorectal neoplasm.

A correlation of $\beta$-catenin expression and cellular localization with the prognosis of several gastrointestinal tumors has been described. It has been found that strong nuclear or cytoplasmic $\beta$-catenin staining in colorectal cancer correlates with more invasive tumor growth, a higher susceptibility of disease recurrence after surgery, and a lower survival rate [207-209]. In HCCs, however, analysis of many cases revealed that mutation and nuclear staining of $\beta$-catenin correlated with less aggressive tumor growth and better survival rates [210,211]. In contrast, in gastric cancers no correlation of $\beta$-catenin nuclear staining with tumor differentiation, tumor type, invasiveness or survival was found [212]. In esophageal carcinoma loss of proteins of the E-cadherin/ $\beta$-catenin adhesive complex correlated with poor prognosis $[213,214]$.
In contrast to diagnostic and prognostic applications therapeutic approaches targeting the Wnt/APC/catenin pathway are even farther from clinical practice. Downregulation of $\beta$-catenin in order to inhibit $\beta$-catenin/Tcf signaling by adenovirus-based or antisense-based approaches has been shown to be critical for tumor cell growth in in vitro and in vivo models $[215,216]$. Instead of downregulating $\beta$-catenin two approaches utilized synthetic Tcf-responsive promoters to drive expression of the apoptosis-inducing gene FADD or an enzyme catalyzing the activation of a cytotoxic prodrug, and both resulted in the selective death of colon cancer cells [217, 218]. However, all approaches targeting tumor cells with deregulated Tcf transcription are hampered by the fact that $\beta$-catenin/ Tcf signaling also plays a critical role in tissue homeostasis as known from knock-out experiments with mice carrying a homozygous deletion of the Tcf- 4 gene. These mice are incapable of maintaining a proliferative stem cell compartment in the small intestine and die shortly after birth [219]. Many questions remain unanswered, but undoubtedly the Wnt/APC/catenin pathway harbors great potential for future applications in cancer diagnosis, staging, and therapy.

\section{References}

1 Funayama N, Fagotto F, McCrea P, Gumbiner BM: Embryonic axis induction by the armadillo repeat domain of beta-catenin: Evidence for intracellular signaling. J Cell Biol 1995;128: 959-968.

2 Cadigan KM, Nusse R: Wnt signaling: A common theme in animal development. Genes Dev 1997; 11:3286-3305.

3 Willert K, Nusse R: Beta-catenin: A key mediator of Wnt signaling. Curr Opin Genet Dev 1998;8:95-102

4 Arias AM, Brown AM, Brennan K: Wnt signalling: Pathway or network? Curr Opin Genet Dev 1999;9:447-454.

5 Polakis P: Wnt signaling and cancer. Genes Dev 2000;14:1837-1851.

6 He TC, Sparks AB, Rago C, Hermeking H, Zawel L, da Costa LT, Morin PJ, Vogelstein B, Kinzler KW: Identification of c-MYC as a target of the APC pathway. Science 1998;281: 1509-1512.

7 Shtutman M, Zhurinsky J, Simcha I, Albanese C, D'Amico M, Pestell R, Ben-Ze'ev A: The cyclin D1 gene is a target of the beta-catenin/ LEF-1 pathway. Proc Natl Acad Sci USA 1999; 96:5522-5527.

8 Tetsu O, McCormick F: Beta-catenin regulates expression of cyclin D1 in colon carcinoma cells. Nature 1999;398:422-426.
9 Crawford HC, Fingleton BM, Rudolph-Owen LA, Goss KJ, Rubinfeld B, Polakis P, Matrisian LM: The metalloproteinase matrilysin is a target of beta-catenin transactivation in intestinal tumors. Oncogene 1999;18:2883-2891.

10 Koh TJ, Bulitta CJ, Fleming JV, Dockray GJ, Varro A, Wang TC: Gastrin is a target of the beta-catenin/TCF-4 growth-signaling pathway in a model of intestinal polyposis. J Clin Invest 2000;106:533-539.

11 Kolligs FT, Nieman MT, Winer I, Hu G, Van Mater D, Feng Y, Smith IM, Wu R, Zhai Y, Cho KR, Fearon ER: ITF-2, a downstream target of the Wnt/TCF pathway, is activated in human cancers with beta-catenin defects and promotes neoplastic transformation. Cancer Cell 2002;1:145-155.

12 Miller JR, Hocking AM, Brown JD, Moon RT: Mechanism and function of signal transduction by the Wnt/beta-catenin and Wnt/Ca2+ pathways. Oncogene 1999;18:7860-7872.

13 Bienz M, Clevers H: Linking colorectal cancer to Wnt signaling. Cell 2000;103:311-320.

14 Fodde R, Smits R, Clevers H: APC, signal transduction and genetic instability in colorectal cancer. Nat Rev Cancer 2001;1:55-67.

15 Fearon ER, Vogelstein B: A genetic model for colorectal tumorigenesis. Cell 1990;61:759767.
16 Renan MJ: How many mutations are required for tumorigenesis? Implications from human cancer data. Mol Carcinog 1993;7:139-146.

17 Pisani P, Parkin DM, Bray F, Ferlay J: Estimates of the worldwide mortality from 25 cancers in 1990. Int J Cancer 1999;83:18-29.

18 Wodarz A, Nusse R: Mechanisms of Wnt signaling in development. Annu Rev Cell Dev Biol 1998;14:59-88.

19 Tamai K, Semenov M, Kato Y, Spokony R, Liu C, Katsuyama Y, Hess F, Saint-Jeannet JP, He $\mathrm{X}$ : LDL-receptor-related proteins in Wnt signal transduction. Nature 2000;407:530-535.

20 Wehrli M, Dougan ST, Caldwell K, O'Keefe L, Schwartz S, Vaizel-Ohayon D, Schejter E, Tomlinson A, DiNardo S: Arrow encodes an LDL-receptor-related protein essential for Wingless signalling. Nature 2000;407:527530.

21 Nusse R: Developmental biology. Making head or tail of Dickkopf. Nature 2001;411:255-256.

22 Leyns L, Bouwmeester T, Kim SH, Piccolo S, De Robertis EM: Frzb-1 is a secreted antagonist of Wnt signaling expressed in the Spemann organizer. Cell 1997;88:747-756.

23 Wang S, Krinks M, Lin K, Luyten FP, Moos M Jr: Frzb, a secreted protein expressed in the Spemann organizer, binds and inhibits Wnt-8. Cell 1997;88:757-766. 
24 Wang S, Krinks M, Moos M Jr: Frzb-1, an antagonist of Wnt-1 and Wnt-8, does not block signaling by Wnts $-3 \mathrm{~A},-5 \mathrm{~A}$, or -11 . Biochem Biophys Res Commun 1997;236:502-504.

25 Bafico A, Gazit A, Pramila T, Finch PW, Yaniv A, Aaronson SA: Interaction of frizzled related protein (FRP) with Wnt ligands and the frizzled receptor suggests alternative mechanisms for FRP inhibition of Wnt signaling. J Biol Chem 1999;274:16180-187.

26 Melkonyan HS, Chang WC, Shapiro JP, Mahadevappa M, Fitzpatrick PA, Kiefer MC, Tomei LD, Umansky SR: SARPs: A family of secreted apoptosis-related proteins. Proc Natl Acad Sci USA 1997;94:13636-13641.

27 Tanaka S, Akiyoshi T, Mori M, Wands JR, Sugimachi K: A novel frizzled gene identified in human esophageal carcinoma mediates APC/beta-catenin signals. Proc Natl Acad Sci USA 1998;95:10164-10169.

28 Axelrod JD, Miller JR, Shulman JM, Moon RT, Perrimon N: Differential recruitment of Dishevelled provides signaling specificity in the planar cell polarity and Wingless signaling pathways. Genes Dev 1998;12:2610-2622.

29 Lee JS, Ishimoto A, Yanagawa S: Characterization of mouse dishevelled (Dvl) proteins in Wnt/Wingless signaling pathway. J Biol Chem 1999;274:21464-1470.

30 Smalley MJ, Sara E, Paterson H, Naylor S, Cook D, Jayatilake H, Fryer LG, Hutchinson L, Fry MJ, Dale TC: Interaction of axin and Dvl-2 proteins regulates Dvl-2-stimulated TCF- dependent transcription. EMBO J 1999; 18:2823-2835.

31 Boutros M, Mihaly J, Bouwmeester T, Mlodzik M: Signaling specificity by Frizzled receptors in Drosophila. Science 2000;288:1825-1828.

32 Noordermeer J, Klingensmith J, Perrimon N, Nusse R: Dishevelled and armadillo act in the wingless signalling pathway in Drosophila. Nature 1994;367:80-83.

33 Li L, Yuan H, Xie W, Mao J, Caruso AM, McMahon A, Sussman DJ, Wu D: Dishevelled proteins lead to two signaling pathways. Regulation of LEF-1 and c-Jun N-terminal kinase in mammalian cells. J Biol Chem 1999;274:129_ 134

34 Moriguchi T, Kawachi K, Kamakura S, Masuyama N, Yamanaka H, Matsumoto K, Kikuchi A, Nishida E: Distinct domains of mouse dishevelled are responsible for the c-Jun N-terminal kinase/stress-activated protein kinase activation and the axis formation in vertebrates. J Biol Chem 1999;274:30957-30962.

35 McEwen DG, Peifer M: Wnt signaling: The naked truth? Curr Biol 2001;11:R524-R526.

36 Kishida M, Koyama S, Kishida S, Matsubara K, Nakashima S, Higano K, Takada R, Takada S, Kikuchi A: Axin prevents Wnt-3a-induced accumulation of beta-catenin. Oncogene 1999; 18:979-985

37 Willert K, Brink M, Wodarz A, Varmus H, Nusse R: Casein kinase 2 associates with and phosphorylates dishevelled. EMBO J 1997;16: 3089-3096.
38 Song DH, Sussman DJ, Seldin DC: Endogenous protein kinase $\mathrm{CK} 2$ participates in Wnt signaling in mammary epithelial cells. J Biol Chem 2000;275:23790-23797.

39 Liu C, Li Y, Semenov M, Han C, Baeg GH, Tan Y, Zhang Z, Lin X, He X: Control of betacatenin phosphorylation/degradation by a dual-kinase mechanism. Cell 2002;108:837847.

40 Amit S, Hatzubai A, Birman Y, Andersen JS, Ben-Shushan E, Mann M, Ben-Neriah Y, Alkalay I: Axin-mediated CKI phosphorylation of beta-catenin at Ser 45:A molecular switch for the Wnt pathway. Genes Dev 2002;16:10661076.

41 Yaron A, Hatzubai A, Davis M, Lavon I, Amit S, Manning AM, Andersen JS, Mann M, Mercurio F, Ben-Neriah Y: Identification of the receptor component of the IkappaBalpha-ubiquitin ligase. Nature 1998;396:590-594.

42 Hart M, Concordet JP, Lassot I, Albert I, del los Santos R, Durand H, Perret C, Rubinfeld B, Margottin F, Benarous R, Polakis P: The F-box protein beta-TrCP associates with phosphorylated beta-catenin and regulates its activity in the cell. Curr Biol 1999;9:207-210.

43 Kitagawa M, Hatakeyama S, Shirane M, Matsumoto M, Ishida N, Hattori K, Nakamichi I, Kikuchi A, Nakayama K, Nakayama K: An Fbox protein, FWD1, mediates ubiquitin-dependent proteolysis of beta-catenin. EMBO J 1999;18:2401-2410.

44 Winston JT, Strack P, Beer-Romero P, Chu CY, Elledge SJ, Harper JW: The SCFbetaTRCP-ubiquitin ligase complex associates specifically with phosphorylated destruction motifs in IkappaBalpha and beta-catenin and stimulates IkappaBalpha ubiquitination in vitro. Genes Dev 1999;13:270-283.

45 Maniatis T: A ubiquitin ligase complex essential for the NF-kappaB, Wnt/Wingless, and Hedgehog signaling pathways. Genes Dev 1999;13:505-510.

46 Aberle H, Bauer A, Stappert J, Kispert A, Kemler R: Beta-catenin is a target for the ubiquitin-proteasome pathway. EMBO J 1997;16: 3797-3804.

47 van Noort M, van de Wetering M, Clevers $\mathrm{H}$ : Identification of two novel regulated serines in the $\mathrm{N}$ terminus of beta-catenin. Exp Cell Res 2002;276:264-272.

48 Yamamoto H, Kishida S, Kishida M, Ikeda S, Takada S, Kikuchi A: Phosphorylation of axin, a Wnt signal negative regulator, by glycogen synthase kinase-3beta regulates its stability. J Biol Chem 1999;274:10681-10684.

49 Rubinfeld B, Albert I, Porfiri E, Fiol C, Munemitsu S, Polakis P: Binding of GSK3beta to the APC-beta-catenin complex and regulation of complex assembly. Science 1996;272:10231026.

50 Yost C, Torres M, Miller JR, Huang E, Kimelman D, Moon RT: The axis-inducing activity, stability, and subcellular distribution of betacatenin is regulated in Xenopus embryos by glycogen synthase kinase 3. Genes Dev 1996; 10:1443-1454.
51 Ikeda S, Kishida S, Yamamoto H, Murai H, Koyama S, Kikuchi A: Axin, a negative regulator of the Wnt signaling pathway, forms a complex with GSK-3beta and beta-catenin and promotes GSK-3beta-dependent phosphorylation of beta-catenin. EMBO J 1998;17:1371-1384.

52 Kishida S, Yamamoto H, Ikeda S, Kishida M, Sakamoto I, Koyama S, Kikuchi A: Axin, a negative regulator of the wnt signaling pathway, directly interacts with adenomatous polyposis coli and regulates the stabilization of beta-catenin. J Biol Chem 1998;273:1082310826.

53 Hart MJ, de los Santos R, Albert IN, Rubinfeld B, Polakis P: Downregulation of beta-catenin by human Axin and its association with the APC tumor suppressor, beta-catenin and GSK3 beta. Curr Biol 1998;8:573-581.

54 Behrens J, Jerchow BA, Wurtele M, Grimm J, Asbrand C, Wirtz R, Kuhl M, Wedlich D, Birchmeier W: Functional interaction of an axin homolog, conductin, with beta-catenin, APC, and GSK3beta. Science 1998;280:596599.

55 Hsu W, Zeng L, Costantini F: Identification of a domain of Axin that binds to the serine/ threonine protein phosphatase $2 \mathrm{~A}$ and a selfbinding domain. J Biol Chem 1999;274:3439_ 3445.

56 Satoh S, Daigo Y, Furukawa Y, Kato T, Miwa N, Nishiwaki T, Kawasoe T, Ishiguro H, Fujita M, Tokino T, Sasaki Y, Imaoka S, Murata M, Shimano T, Yamaoka Y, Nakamura Y: AXIN1 mutations in hepatocellular carcinomas, and growth suppression in cancer cells by virusmediated transfer of AXIN1. Nat Genet 2000; 24:245-250.

57 Liu W, Dong X, Mai M, Seelan RS, Taniguchi K, Krishnadath KK, Halling KC, Cunningham JM, Boardman LA, Qian C, Christensen E, Schmidt SS, Roche PC, Smith DI, Thibodeau $\mathrm{SN}$ : Mutations in AXIN2 cause colorectal cancer with defective mismatch repair by activating beta-catenin/TCF signalling. Nat Genet 2000;26:146-147.

58 Sparks AB, Morin PJ, Vogelstein B, Kinzler KW: Mutational analysis of the APC/beta-cate$\mathrm{nin} / \mathrm{Tcf}$ pathway in colorectal cancer. Cancer Res 1998:58:1130-1134.

59 Sutherland C, Leighton IA, Cohen P: Inactivation of glycogen synthase kinase- 3 beta by phosphorylation: New kinase connections in insulin and growth-factor signalling. Biochem $\mathbf{J}$ 1993;296:15-19.

60 Li L, Yuan H, Weaver CD, Mao J, Farr GH 3rd, Sussman DJ, Jonkers J, Kimelman D, Wu D: Axin and Frat 1 interact with dvl and GSK, bridging Dvl to GSK in Wnt-mediated regulation of LEF-1. EMBO J 1999; 18:4233-4240.

61 Porter AC, Vaillancourt RR: Tyrosine kinase receptor-activated signal transduction pathways which lead to oncogenesis. Oncogene 1998;17:1343-1352.

62 Murray NR, Davidson LA, Chapkin RS, Clay Gustafson W, Schattenberg DG, Fields AP Overexpression of protein kinase $\mathrm{C}$ betaII induces colonic hyperproliferation and increased sensitivity to colon carcinogenesis. J Cell Biol 1999;145:699-711. 
63 Kim E, Arnould T, Sellin LK, Benzing T, Fan MJ, Gruning W, Sokol SY, Drummond I, Walz $\mathrm{G}$ : The polycystic kidney disease 1 gene product modulates Wnt signaling. J Biol Chem 1999;274:4947-4953.

64 Lawlor MA, Alessi DR: PKB/Akt: A key mediator of cell proliferation, survival and insulin responses? J Cell Sci 2001;114:2903-2910.

65 Scheid MP, Woodgett JR: PKB/AKT: Functional insights from genetic models. Nat Rev Mol Cell Biol 2001;2:760-768.

66 Hakam A, Yeatman TJ, Lu L, Mora L, Marcet G, Nicosia SV, Karl RC, Coppola D: Expression of insulin-like growth factor-1 receptor in human colorectal cancer. Hum Pathol 1999;30: 1128-1133.

67 Davidson LA, Jiang YH, Derr JN, Aukema HM, Lupton JR, Chapkin RS: Protein kinase C isoforms in human and rat colonic mucosa. Arch Biochem Biophys 1994;312:547-553.

68 Pongracz J, Clark P, Neoptolemos JP, Lord $\mathrm{JM}$ : Expression of protein kinase $\mathrm{C}$ isoenzymes in colorectal cancer tissue and their differential activation by different bile acids. Int $\mathbf{J}$ Cancer 1995;61:35-39.

69 Groden J, Thliveris A, Samowitz W, Carlson M, Gelbert L, Albertsen H, Joslyn G, Stevens J, Spirio L, Robertson M, et al: Identification and characterization of the familial adenomatous polyposis coli gene. Cell 1991;66:589-600.

70 Kinzler KW, Nilbert MC, Su LK, Vogelstein B, Bryan TM, Levy DB, Smith KJ, Preisinger AC, Hedge P, McKechnie D, et al: Identification of FAP locus genes from chromosome $5 \mathrm{q} 21$. Science 1991;253:661-665.

71 Kinzler KW, Nilbert MC, Vogelstein B, Bryan TM, Levy DB, Smith KJ, Preisinger AC, Hamilton SR, Hedge P, Markham A, et al: Identification of a gene located at chromosome $5 \mathrm{q} 21$ that is mutated in colorectal cancers. Science 1991;251:1366-1370.

72 Kinzler KW, Vogelstein B: Lessons from hereditary colorectal cancer. Cell 1996;87:159170.

73 Lal G, Gallinger S: Familial adenomatous polyposis. Semin Surg Oncol 2000;18:314-323.

74 Munemitsu S, Albert I, Souza B, Rubinfeld B, Polakis P: Regulation of intracellular beta-catenin levels by the adenomatous polyposis coli (APC) tumor-suppressor protein. Proc Nat Acad Sci USA 1995;92:3046-3050.

75 Rubinfeld B, Souza B, Albert I, Muller O, Chamberlain SH, Masiarz FR, Munemitsu S, Polakis P: Association of the APC gene product with beta-catenin. Science 1993;262:17311734.

$76 \mathrm{Su}$ LK, Vogelstein B, Kinzler KW: Association of the APC tumor suppressor protein with catenins. Science 1993;262:1734-1737.

77 Miyoshi Y, Nagase H, Ando H, Horii A, Ichii S, Nakatsuru S, Aoki T, Miki Y, Mori T, Nakamura Y: Somatic mutations of the APC gene in colorectal tumors: Mutation cluster region in the APC gene. Hum Mol Genet 1992;1:229_ 233.

Wnt Signaling and Gastrointestinal Tumorigenesis
78 Rubinfeld B, Albert I, Porfiri E, Munemitsu S, Polakis P: Loss of beta-catenin regulation by the APC tumor suppressor protein correlates with loss of structure due to common somatic mutations of the gene. Cancer Res 1997;57: 4624-4630.

79 Hulsken J, Behrens J, Birchmeier W: Tumorsuppressor gene products in cell contacts: The cadherin-APC-armadillo connection. Curr Opin Cell Biol 1994;6:711-716.

80 Hulsken J, Birchmeier W, Behrens J: E-cadherin and APC compete for the interaction with beta-catenin and the cytoskeleton. J Cell Biol 1994;127:2061-2069.

81 Rubinfeld B, Souza B, Albert I, Munemitsu S, Polakis P: The APC protein and E-cadherin form similar but independent complexes with alpha-catenin, beta-catenin, and plakoglobin. J Biol Chem 1995;270:5549-5555.

82 Smith KJ, Levy DB, Maupin P, Pollard TD, Vogelstein B, Kinzler KW: Wild-type but not mutant APC associates with the microtubule cytoskeleton. Cancer Res 1994;54:3672-3675.

83 Munemitsu S, Souza B, Muller O, Albert I, Rubinfeld B, Polakis P: The APC gene product associates with microtubules in vivo and promotes their assembly in vitro. Cancer Res 1994;54:3676-3681.

84 Su LK, Burrell M, Hill DE, Gyuris J, Brent R, Wiltshire R, Trent J, Vogelstein B, Kinzler KW: APC binds to the novel protein EB1. Cancer Res 1995;55:2972-2977.

85 Matsumine A, Ogai A, Senda T, Okumura N, Satoh K, Baeg GH, Kawahara T, Kobayashi S, Okada M, Toyoshima K, Akiyama T: Binding of APC to the human homolog of the Drosophila discs large tumor suppressor protein. Science 1996;272:1020-1023.

86 Kawasaki Y, Senda T, Ishidate T, Koyama R, Morishita T, Iwayama Y, Higuchi O, Akiyama T: Asef, a link between the tumor suppressor APC and G-protein signaling. Science 2000; 289:1194-1197.

87 Matsuzawa SI, Reed JC: Siah-1, SIP, and Ebi collaborate in a novel pathway for beta-catenin degradation linked to p53 responses. Mol Cell 2001;7:915-926.

88 Liu J, Stevens J, Rote CA, Yost HJ, Hu Y, Neufeld KL, White RL, Matsunami N: Siah-1 mediates a novel beta-catenin degradation pathway linking p53 to the adenomatous polyposis coli protein. Mol Cell 2001;7:927-936.

89 Kawahara K, Morishita T, Nakamura T, Hamada F, Toyoshima K, Akiyama T: Down-regulation of beta-catenin by the colorectal tumor suppressor APC requires association with Axin and beta-catenin. J Biol Chem 2000;275:83698374.

$90 \mathrm{Hu}$ G, Zhang S, Vidal M, Baer JL, Xu T, Fearon ER: Mammalian homologs of seven in absentia regulate DCC via the ubiquitin-proteasome pathway. Genes Dev 1997;11:27012714.

91 Morin PJ, Sparks AB, Korinek V, Barker N, Clevers H, Vogelstein B, Kinzler KW: Activation of beta-catenin-Tcf signaling in colon cancer by mutations in beta-catenin or APC. Science 1997;275:1787-1790.
92 Kitaeva MN, Grogan L, Williams JP, Dimond E, Nakahara K, Hausner P, DeNobile JW, Soballe PW, Kirsch IR: Mutations in beta-catenin are uncommon in colorectal cancer occurring in occasional replication errorpositive tumors. Cancer Res 1997;57:44784481.

93 Iwao K, Nakamori S, Kameyama M, Imaoka S, Kinoshita M, Fukui T, Ishiguro S, Nakamura Y, Miyoshi Y: Activation of the betacatenin gene by interstitial deletions involving exon 3 in primary colorectal carcinomas without adenomatous polyposis coli mutations. Cancer Res 1998;58:1021-1026.

94 Mirabelli-Primdahl L, Gryfe R, Kim H, Millar A, Luceri C, Dale D, Holowaty E, Bapat B, Gallinger S, Redston M: Beta-catenin mutations are specific for colorectal carcinomas with microsatellite instability but occur in endometrial carcinomas irrespective of mutator pathway. Cancer Res 1999;59:33463351.

95 Polakis P, Hart M, Rubinfeld B: Defects in the regulation of beta-catenin in colorectal cancer. Adv Exp Med Biol 1999;470:23-32.

96 Samowitz WS, Powers MD, Spirio LN, Nollet F, van Roy F, Slattery ML: Beta-catenin mutations are more frequent in small colorectal adenomas than in larger adenomas and invasive carcinomas. Cancer Res 1999;59:14421444.

97 Alman BA, Li C, Pajerski ME, Diaz-Cano S, Wolfe $\mathrm{HJ}$ : Increased beta-catenin protein and somatic APC mutations in sporadic aggressive fibromatoses (desmoid tumors). Am J Pathol 1997;151:329-334.

98 Shitoh K, Konishi F, Iijima T, Ohdaira T, Sakai K, Kanazawa K, Miyaki M: A novel case of a sporadic desmoid tumour with mutation of the beta catenin gene. J Clin Pathol 1999;52:695-696.

99 Tejpar S, Nollet F, Li C, Wunder JS, Michils G, dal Cin P, Van Cutsem E, Bapat B, van Roy F, Cassiman JJ, Alman BA: Predominance of beta-catenin mutations and betacatenin dysregulation in sporadic aggressive fibromatosis (desmoid tumor). Oncogene 1999; 18:6615-6620.

100 Deka J, Kuhlmann J, Muller O: A domain within the tumor suppressor protein APC shows very similar biochemical properties as the microtubule-associated protein tau. Eur J Biochem 1998;253:591-597.

101 Askham JM, Moncur P, Markham AF, Morrison EE: Regulation and function of the interaction between the APC tumour suppressor protein and EB1. Oncogene 2000;19: 1950-1958.

102 Fodde R, Kuipers J, Rosenberg C, Smits R, Kielman M, Gaspar C, van Es JH, Breukel C, Wiegant J, Giles RH, Clevers H: Mutations in the APC tumour suppressor gene cause chromosomal instability. Nat Cell Biol 2001;3. 433-438. 
103 Kaplan KB, Burds AA, Swedlow JR, Bekir SS, Sorger PK, Nathke IS: A role for the adenomatous polyposis coli protein in chromosome segregation. Nat Cell Biol 2001;3:429432.

104 Peifer M, Wieschaus E: The segment polarity gene armadillo encodes a functionally modular protein that is the Drosophila homolog of human plakoglobin. Cell 1990;63:11671176.

105 Peifer M, Rauskolb C, Williams M, Riggleman B, Wieschaus E: The segment polarity gene armadillo interacts with the wingless signaling pathway in both embryonic and adult pattern formation. Development 1991;111: 1029-1043.

106 Barth AI, Nathke IS, Nelson WJ: Cadherins, catenins and APC protein: Interplay between cytoskeletal complexes and signaling pathways. Curr Opin Cell Biol 1997;9:683-690.

107 Huber O, Bierkamp C, Kemler R: Cadherins and catenins in development. Curr Opin Cell Biol 1996;8:685-691.

108 Muller T, Choidas A, Reichmann E, Ullrich A: Phosphorylation and free pool of betacatenin are regulated by tyrosine kinases and tyrosine phosphatases during epithelial cell migration. J Biol Chem 1999;274:1017310183.

109 Hazan RB, Norton L: The epidermal growth factor receptor modulates the interaction of E-cadherin with the actin cytoskeleton. J Biol Chem 1998;273:9078-9084.

110 Hiscox S, Jiang WG: Hepatocyte growth factor/scatter factor disrupts epithelial tumour cell-cell adhesion: Involvement of beta-catenin. Anticancer Res 1999;19:509-517.

111 Hiscox S, Jiang WG: Association of the HGF/ SF receptor, c-met, with the cell-surface adhesion molecule, E-cadherin, and catenins in human tumor cells. Biochem Biophys Res Commun 1999;261:406-411.

112 Kanai Y, Ochiai A, Shibata T, Oyama T, Ushijima S, Akimoto S, Hirohashi S: c-erbB-2 gene product directly associates with betacatenin and plakoglobin. Biochem Biophys Res Commun 1995;208:1067-1072.

113 Korinek V, Barker N, Morin PJ, van Wichen D, de Weger R, Kinzler KW, Vogelstein B, Clevers $\mathrm{H}$ : Constitutive transcriptional activation by a beta-catenin-Tcf complex in APC-/- colon carcinoma. Science 1997;275: 1784-1787.

114 Kolligs FT, Hu G, Dang CV, Fearon ER: Neoplastic transformation of RK3E by mutant beta-catenin requires deregulation of Tcf/Lef transcription but not activation of cmyc expression. Mol Cell Biol 1999;19:56965706.

115 Orford K, Orford CC, Byers SW: Exogenous expression of beta-catenin regulates contact inhibition, anchorage-independent growth, anoikis, and radiation-induced cell cycle arrest. J Cell Biol 1999;146:855-868.

116 Gat U, DasGupta R, Degenstein L, Fuchs E: De Novo hair follicle morphogenesis and hair tumors in mice expressing a truncated betacatenin in skin. Cell 1998;95:605-614.
117 Romagnolo B, Berrebi D, Saadi-Keddoucci S, Porteu A, Pichard AL, Peuchmaur M, Vandewalle A, Kahn A, Perret C: Intestinal dysplasia and adenoma in transgenic mice after overexpression of an activated beta-catenin. Cancer Res 1999;59:3875-3879.

118 Chan EF: Pilomatricomas contain activating mutations in beta-catenin. J Am Acad Dermatol 2000;43:701-702.

119 Chan EF, Gat U, McNiff JM, Fuchs E: A common human skin tumour is caused by activating mutations in beta-catenin. Nat Genet 1999;21:410-413.

120 Miyaki M, Iijima T, Kimura J, Yasuno M, Mori T, Hayashi Y, Koike M, Shitara N, Iwama T, Kuroki T: Frequent mutation of betacatenin and APC genes in primary colorectal tumors from patients with hereditary nonpolyposis colorectal cancer. Cancer Res 1999; 59:4506-4509.

121 Koch A, Denkhaus D, Albrecht S, Leuschner I, von Schweinitz D, Pietsch T: Childhood hepatoblastomas frequently carry a mutated degradation targeting box of the beta-catenin gene. Cancer Res 1999;59:269-273.

122 Jeng YM, Wu MZ, Mao TL, Chang MH, Hsu HC: Somatic mutations of beta-catenin play a crucial role in the tumorigenesis of sporadic hepatoblastoma. Cancer Lett 2000;152:4551 .

123 Wei Y, Fabre M, Branchereau S, Gauthier F, Perilongo G, Buendia MA: Activation of beta-catenin in epithelial and mesenchymal hepatoblastomas. Oncogene 2000;19:498504.

124 de La Coste A, Romagnolo B, Billuart P, Renard CA, Buendia MA, Soubrane O, Fabre M, Chelly J, Beldjord C, Kahn A, Perret C: Somatic mutations of the beta-catenin gene are frequent in mouse and human hepatocellular carcinomas. Proc Natl Acad Sci USA 1998; 95:8847-8851.

125 Miyoshi Y, Iwao K, Nagasawa Y, Aihara T, Sasaki Y, Imaoka S, Murata M, Shimano T, Nakamura Y: Activation of the beta-catenin gene in primary hepatocellular carcinomas by somatic alterations involving exon 3. Cancer Res 1998;58:2524-2527.

126 Nhieu JT, Renard CA, Wei Y, Cherqui D, Zafrani ES, Buendia MA: Nuclear accumulation of mutated beta-catenin in hepatocellular carcinoma is associated with increased cell proliferation. Am J Pathol 1999;155:703710.

127 Legoix P, Bluteau O, Bayer J, Perret C, Balabaud C, Belghiti J, Franco D, Thomas G, Laurent-Puig P, Zucman-Rossi J: Beta-catenin mutations in hepatocellular carcinoma correlate with a low rate of loss of heterozygosity. Oncogene 1999;18:4044-4046.

128 Huang H, Fujii H, Sankila A, Mahler-Araujo BM, Matsuda M, Cathomas G, Ohgaki H: Beta-catenin mutations are frequent in human hepatocellular carcinomas associated with hepatitis $\mathrm{C}$ virus infection. Am $\mathrm{J}$ Pathol 1999;155:1795-1801

129 Choi YW, Heath EI, Heitmiller R, Forastiere AA, Wu TT: Mutations in beta-catenin and APC genes are uncommon in esophageal and esophagogastric junction adenocarcinomas. Mod Pathol 2000;13:1055-1059.
130 Wijnhoven BP, Nollet F, De Both NJ, Tilanus HW, Dinjens WN: Genetic alterations involving exon 3 of the beta-catenin gene do not play a role in adenocarcinomas of the esophagus. Int J Cancer 2000;86:533-537.

131 Bian YS, Osterheld MC, Bosman FT, Fontolliet C, Benhattar J: Nuclear accumulation of beta-catenin is a common and early event during neoplastic progression of Barrett esophagus. Am J Clin Pathol 2000;114:583590

132 Osterheld MC, Bian YS, Bosman FT, Benhat$\operatorname{tar} \mathrm{J}$, Fontolliet C: Beta-catenin expression and its association with prognostic factors in adenocarcinoma developed in Barrett esophagus. Am J Clin Pathol 2002;117:451-456.

133 Bailey T, Biddlestone L, Shepherd N, Barr H, Warner P, Jankowski J: Altered cadherin and catenin complexes in the Barrett's esophagusdysplasia-adenocarcinoma sequence: Correlation with disease progression and dedifferentiation. Am J Pathol 1998;152:135-144.

134 Park WS, Oh RR, Park JY, Lee SH, Shin MS, Kim YS, Kim SY, Lee HK, Kim PJ, Oh ST, Yoo NJ, Lee JY: Frequent somatic mutations of the beta-catenin gene in intestinal-type gastric cancer. Cancer Res 1999;59:4257-4260.

135 Sekine S, Shibata T, Yamauchi Y, Nakanishi Y, Shimoda T, Sakamoto M, Hirohashi S: Beta-catenin mutations in sporadic fundic gland polyps. Virchows Arch 2002;440:381386

136 Caca K, Kolligs FT, Ji X, Hayes M, Qian J, Yahanda A, Rimm DL, Costa J, Fearon ER Beta- and gamma-catenin mutations, but not E-cadherin inactivation, underlie T-cell factor/lymphoid enhancer factor transcriptional deregulation in gastric and pancreatic cancer. Cell Growth Differ 1999;10:369-376.

137 Gerdes B, Ramaswamy A, Simon B, Pietsch T, Bastian D, Kersting M, Moll R, Bartsch D: Analysis of beta-catenin gene mutations in pancreatic tumors. Digestion 1999;60:544548.

138 Abraham SC, Wu TT, Klimstra DS, Finn LS, Lee JH, Yeo CJ, Cameron JL, Hruban RH: Distinctive molecular genetic alterations in sporadic and familial adenomatous polyposis-associated pancreatoblastomas: Frequent alterations in the APC/beta-catenin pathway and chromosome 11p. Am J Pathol 2001;159: 1619-1627.

139 Abraham SC, Wu TT, Hruban RH, Lee JH, Yeo CJ, Conlon K, Brennan M, Cameron JL, Klimstra DS: Genetic and immunohistochemical analysis of pancreatic acinar cell carcinoma: Frequent allelic loss on chromosome $11 \mathrm{p}$ and alterations in the APC/betacatenin pathway. Am J Pathol 2002;160:953962.

140 Abraham SC, Klimstra DS, Wilentz RE, Yeo CJ, Conlon K, Brennan M, Cameron JL, Wu TT, Hruban RH: Solid-pseudopapillary tumors of the pancreas are genetically distinct from pancreatic ductal adenocarcinomas and almost always harbor beta-catenin mutations. Am J Pathol 2002;160:1361-1369. 
141 Yanagisawa N, Mikami T, Saegusa M, Okayasu I: More frequent beta-catenin exon 3 mutations in gallbladder adenomas than in carcinomas indicate different lineages. Cancer Res 2001;61:19-22.

142 Chang HJ, Jee CD, Kim WH: Mutation and altered expression of beta-cduring gallbladder carcinogenesis. Am J Surg Pathol 2002;26: 758-766.

143 Sugimachi K, Taguchi K, Aishima S, Tanaka S, Shimada M, Kajiyama K, Sugimachi K, Tsuneyoshi M: Altered expression of betacatenin without genetic mutation in intrahepatic cholangiocarcinoma. Mod Pathol 2001; 14:900-905.

144 Rashid A, Gao YT, Bhakta S, Shen MC, Wang BS, Deng J, Fraumeni JF Jr, Hsing AW: Beta-catenin mutations in biliary tract cancers: A population-based study in China. Cancer Res 2001;61:3406-3409.

145 Fukuchi T, Sakamoto M, Tsuda H, Maruyama K, Nozawa S, Hirohashi S: Beta-catenin mutation in carcinoma of the uterine endometrium. Cancer Res 1998;58:3526-3528.

146 Palacios J, Gamallo C: Mutations in the betacatenin gene (CTNNB1) in endometrioid ovarian carcinomas. Cancer Res 1998;58: 1344-1347.

147 Gamallo C, Palacios J, Moreno G, Calvo de Mora J, Suarez A, Armas A: Beta-catenin expression pattern in stage I and II ovarian carcinomas: Relationship with beta-catenin gene mutations, clinicopathological features, and clinical outcome. Am J Pathol 1999;155: 527-536.

148 Wright K, Wilson P, Morland S, Campbell I, Walsh M, Hurst T, Ward B, Cummings M, Chenevix-Trench G: Beta-catenin mutation and expression analysis in ovarian cancer: Exon 3 mutations and nuclear translocation in $16 \%$ of endometrioid tumours. Int J Cancer 1999;82:625-629.

149 Rimm DL, Caca K, Hu G, Harrison FB, Fearon ER: Frequent nuclear/cytoplasmic localization of beta-catenin without exon 3 mutations in malignant melanoma. Am $\mathbf{J}$ Pathol 1999;154:325-329.

150 Garcia-Rostan G, Tallini G, Herrero A, D'Aquila TG, Carcangiu ML, Rimm DL: Frequent mutation and nuclear localization of beta-catenin in anaplastic thyroid carcinoma. Cancer Res 1999;59:1811-1815.

151 Voeller HJ, Truica CI, Gelmann EP: Betacatenin mutations in human prostate cancer. Cancer Res 1998;58:2520-2523.

152 Koesters R, Ridder R, Kopp-Schneider A, Betts D, Adams V, Niggli F, Briner J, von Knebel Doeberitz M: Mutational activation of the beta-catenin proto-oncogene is a common event in the development of Wilms' tumors. Cancer Res 1999;59:3880-3882.

153 Sunaga N, Kohno T, Kolligs FT, Fearon ER, Saito R, Yokota J: Constitutive activation of the Wnt signaling pathway by CTNNB1 (beta-catenin) mutations in a subset of human lung adenocarcinoma. Genes Chromosomes Cancer 2001;30:316-321.
154 Zurawel RH, Chiappa SA, Allen C, Raffel C: Sporadic medulloblastomas contain oncogenic beta-catenin mutations. Cancer Res 1998; 58:896-899.

155 Ben-Ze'ev A, Geiger B: Differential molecular interactions of beta-catenin and plakoglobin in adhesion, signaling and cancer. Curr Opin Cell Biol 1998;10:629-639.

156 Shibata T, Gotoh M, Ochiai A, Hirohashi S: Association of plakoglobin with APC, a tumor suppressor gene product, and its regulation by tyrosine phosphorylation. Biochem Biophys Res Commun 1994;203:519-522.

157 Kodama S, Ikeda S, Asahara T, Kishida M, Kikuchi A: Axin directly interacts with plakoglobin and regulates its stability. J Biol Chem 1999;274:27682-27688.

158 Miravet S, Piedra J, Miro F, Itarte E, Garcia de Herreros A, Dunach M: The transcriptional factor Tcf-4 contains different binding sites for beta-catenin and plakoglobin. J Biol Chem 2002;277:1884-1891.

159 Simcha I, Shtutman M, Salomon D, Zhurinsky J, Sadot E, Geiger B, Ben-Ze'ev A: Differential nuclear translocation and transactivation potential of beta-catenin and plakoglobin. J Cell Biol 1998;141:1433-1448.

160 Kolligs FT, Kolligs B, Hajra KM, Hu G, Tani M, Cho KR, Fearon ER: Gamma-catenin is regulated by the APC tumor suppressor and its oncogenic activity is distinct from that of beta-catenin. Genes Dev 2000;14:13191331.

161 Behrens J, von Kries JP, Kuhl M, Bruhn L, Wedlich D, Grosschedl R, Birchmeier W: Functional interaction of beta-catenin with the transcription factor LEF-1. Nature 1996; 382:638-642.

162 Molenaar M, van de Wetering M, Oosterwegel M, Peterson-Maduro J, Godsave S, Korinek V, Roose J, Destree O, Clevers H: XTcf-3 transcription factor mediates beta-catenin-induced axis formation in Xenopus embryos. Cell 1996;86:391-399.

163 Hecht A, Vleminckx K, Stemmler MP, van Roy F, Kemler R: The p300/CBP acetyltransferases function as transcriptional coactivators of beta-catenin in vertebrates. EMBO J 2000;19:1839-1850.

164 Sun Y, Kolligs FT, Hottiger MO, Mosavin R, Fearon ER, Nabel GJ: Regulation of betacatenin transformation by the p300 transcriptional coactivator. Proc Natl Acad Sci USA 2000;97:12613-12618.

165 Takemaru KI, Moon RT: The transcriptional coactivator CBP interacts with beta-catenin to activate gene expression. J Cell Biol 2000; 149:249-254.

166 Barker N, Hurlstone A, Musisi H, Miles A, Bienz M, Clevers H: The chromatin remodelling factor Brg-1 interacts with beta-catenin to promote target gene activation. EMBO J 2001;20:4935-4943.

167 Bauer A, Huber O, Kemler R: Pontin52, an interaction partner of beta-catenin, binds to the TATA box binding protein. Proc Natl Acad Sci USA 1998;95:14787-14792.

168 Morin PJ: Beta-catenin signaling and cancer. Bioessays 1999;21:1021-1030.
169 Duval A, Iacopetta B, Ranzani GN, Lothe RA, Thomas G, Hamelin R: Variable mutation frequencies in coding repeats of TCF-4 and other target genes in colon, gastric and endometrial carcinoma showing microsatellite instability. Oncogene 1999;18:68066809.

170 Duval A, Gayet J, Zhou XP, Iacopetta B, Thomas G, Hamelin R: Frequent frameshift mutations of the TCF-4 gene in colorectal cancers with microsatellite instability. Cancer Res 1999;59:4213-4215.

171 Duval A, Rolland S, Tubacher E, Bui H, Thomas G, Hamelin R: The human T-cell transcription factor-4 gene: Structure, extensive characterization of alternative splicings, and mutational analysis in colorectal cancer cell lines. Cancer Res 2000;60:3872-3879.

172 Roose J, Clevers H: TCF transcription factors: molecular switches in carcinogenesis. Biochim Biophys Acta 1999;1424:M23M37.

173 Roose J, Molenaar M, Peterson J, Hurenkamp J, Brantjes H, Moerer P, van de Wetering M, Destree O, Clevers H: The Xenopus Wnt effector XTcf-3 interacts with Grouchorelated transcriptional repressors. Nature 1998;395:608-612.

174 Cavallo RA, Cox RT, Moline MM, Roose J, Polevoy GA, Clevers H, Peifer M, Bejsovec A: Drosophila Tcf and Groucho interact to repress Wingless signalling activity. Nature 1998;395:604-608.

175 Hovanes K, Li TW, Munguia JE, Truong T, Milovanovic T, Lawrence Marsh J, Holcombe RF, Waterman ML: Beta-catenin-sensitive isoforms of lymphoid enhancer factor-1 are selectively expressed in colon cancer. Nat Genet 2001;28:53-57.

176 Sikora K, Chan S, Evan G, Gabra H, Markham N, Stewart J, Watson J: C-myc oncogene expression in colorectal cancer. Cancer 1987; 59:1289-1295.

177 Erisman MD, Scott JK, Watt RA, Astrin SM: The c-myc protein is constitutively expressed at elevated levels in colorectal carcinoma cell lines. Oncogene 1988;2:367-378.

178 Finley GG, Schulz NT, Hill SA, Geiser JR, Pipas JM, Meisler AI: Expression of the myc gene family in different stages of human colorectal cancer. Oncogene 1989;4:963-971.

179 Imaseki H, Hayashi H, Taira M, Ito Y, Tabata $\mathrm{Y}$, Onoda S, Isono K, Tatibana M: Expression of c-myc oncogene in colorectal polyps as a biological marker for monitoring malignant potential. Cancer 1989;64:704-709.

180 Smith DR, Myint T, Goh HS: Over-expression of the c-myc proto-oncogene in colorectal carcinoma. Br J Cancer 1993;68:407-413.

181 Erisman MD, Rothberg PG, Diehl RE, Morse CC, Spandorfer JM, Astrin SM: Deregulation of c-myc gene expression in human colon carcinoma is not accompanied by amplification or rearrangement of the gene. Mol Cell Biol 1985;5:1969-1976.

$182 \mathrm{Kamb}$ A: Role of a cell cycle regulator in hereditary and sporadic cancer. Cold Spring Harb Symp Quant Biol 1994;59:39-47. 
183 Ohhara M, Esumi M, Kurosu Y: Activation but not inactivation of the MTS1 gene is associated with primary colorectal carcinomas. Biochem Biophys Res Commun 1996;226: 791-795.

184 Sherr CJ: Cancer cell cycles. Science 1996; 274:1672-1677.

185 Sellers WR, Kaelin WG Jr: Role of the retinoblastoma protein in the pathogenesis of human cancer. J Clin Oncol 1997;15:33013312.

186 Brabletz T, Jung A, Dag S, Hlubek F, Kirchner $\mathrm{T}$ : Beta-catenin regulates the expression of the matrix metalloproteinase-7 in human colorectal cancer. Am J Pathol 1999;155: 1033-1038.

187 Wilson CL, Heppner KJ, Labosky PA, Hogan $\mathrm{BL}$, Matrisian LM: Intestinal tumorigenesis is suppressed in mice lacking the metalloproteinase matrilysin. Proc Natl Acad Sci USA 1997;94:1402-1407.

$188 \mathrm{Xu}$ L, Corcoran RB, Welsh JW, Pennica D, Levine AJ: WISP-1 is a Wnt-1- and beta-catenin-responsive oncogene. Genes Dev 2000; 14:585-595.

189 Roose J, Huls G, van Beest M, Moerer P, van der Horn K, Goldschmeding R, Logtenberg T, Clevers H: Synergy between tumor suppressor APC and the beta-catenin-Tcf4 target Tcf1. Science 1999;285:1923-1926.

190 Yan D, Wiesmann M, Rohan M, Chan V, Jefferson AB, Guo L, Sakamoto D, Caothien RH, Fuller JH, Reinhard C, Garcia PD, Randazzo FM, Escobedo J, Fantl WJ, Williams LT: Elevated expression of axin2 and hnkd mRNA provides evidence that Wnt/beta-catenin signaling is activated in human colon tumors. Proc Natl Acad Sci USA 2001;98: 14973-14978.

191 Jho EH, Zhang T, Domon C, Joo CK, Freund JN, Costantini F: Wnt/beta-catenin/Tcf signaling induces the transcription of Axin2, a negative regulator of the signaling pathway. Mol Cell Biol 2002;22:1172-1183.

192 Lustig B, Jerchow B, Sachs M, Weiler S, Pietsch T, Karsten U, van de Wetering M, Clevers H, Schlag PM, Birchmeier W, Behrens J: Negative feedback loop of Wnt signaling through upregulation of conductin/axin2 in colorectal and liver tumors. Mol Cell Biol 2002;22:1184-1193.

193 Leung JY, Kolligs FT, Wu R, Zhai Y, Kuick R, Hanash S, Cho KR, Fearon ER: Activation of AXIN2 expression by beta-catenin/TCF: A feedback repressor pathway regulating Wnt signaling. J Biol Chem 2002;277:2165721665.

194 van der Heyden MA, Rook MB, Hermans MM, Rijksen G, Boonstra J, Defize LH, Destree $\mathrm{OH}$ : Identification of connexin43 as a functional target for Wnt signalling. J Cell Sci 1998;111:1741-1749.

195 Rockman SP, Currie SA, Ciavarella M, Vincan E, Dow C, Thomas RJ, Phillips WA: Id2 is a target of the beta-catenin/T cell factor pathway in colon carcinoma. $\mathrm{J}$ Biol Chem 2001;276:45113-45119.
196 He TC, Chan TA, Vogelstein B, Kinzler KW: PPARdelta is an APC-regulated target of nonsteroidal anti-inflammatory drugs. Cell 1999; 99:335-345.

197 Zhang T, Otevrel T, Gao Z, Gao Z, Ehrlich SM, Fields JZ, Boman BM: Evidence that APC regulates survivin expression: A possible mechanism contributing to the stem cell origin of colon cancer. Cancer Res 2001;61: 8664-8667.

198 Mann B, Gelos M, Siedow A, Hanski ML, Gratchev A, Ilyas M, Bodmer WF, Moyer MP, Riecken EO, Buhr HJ, Hanski C: Target genes of beta-catenin-T cell-factor/lymphoidenhancer-factor signaling in human colorectal carcinomas. Proc Natl Acad Sci USA 1999; 96:1603-1608

199 Ishiguro H, Furukawa Y, Daigo Y, Miyoshi Y, Nagasawa Y, Nishiwaki T, Kawasoe T, Fujita M, Satoh S, Miwa N, Fujii Y, Nakamura $\mathrm{Y}$ : Isolation and characterization of human NBL4, a gene involved in the beta-catenin/tcf signaling pathway. Jpn J Cancer Res 2000;91: 597-603.

200 Kawasoe T, Furukawa Y, Daigo Y, Nishiwaki T, Ishiguro H, Fujita M, Satoh S, Miwa N, Nagasawa Y, Miyoshi Y, Ogawa M, Nakamura $\mathrm{Y}$ : Isolation and characterization of a novel human gene, DRCTNNB1A, the expression of which is down-regulated by beta-catenin. Cancer Res 2000;60:3354-3358.

201 Yamada T, Takaoka AS, Naishiro Y, Hayashi R, Maruyama K, Maesawa C, Ochiai A, Hirohashi S: Transactivation of the multidrug resistance 1 gene by $\mathrm{T}$-cell factor 4/beta-catenin complex in early colorectal carcinogenesis. Cancer Res 2000;60:4761-4766.

202 Arnold SJ, Stappert J, Bauer A, Kispert A, Herrmann BG, Kemler R: Brachyury is a target gene of the $\mathrm{Wnt} /$ beta-catenin signaling pathway. Mech Dev 2000;91:249-258.

203 van der Luijt $R$, Khan PM, Vasen $H$, van Leeuwen C, Tops C, Roest P, den Dunnen J, Fodde R: Rapid detection of translation-terminating mutations at the adenomatous polyposis coli (APC) gene by direct protein truncation test. Genomics 1994;20:1-4.

204 Ballhausen WG: Genetic testing for familial adenomatous polyposis. Ann NY Acad Sci 2000;910:36-49.

205 Ahlquist DA, Skoletsky JE, Boynton KA, Harrington JJ, Mahoney DW, Pierceall WE, Thibodeau SN, Shuber AP: Colorectal cancer screening by detection of altered human DNA in stool: Feasibility of a multitarget assay panel. Gastroenterology 2000;119: 1219-1227.

206 Zhou W, Goodman SN, Galizia G, Lieto E, Ferraraccio F, Pignatelli C, Purdie CA, Piris J, Morris R, Harrison DJ, Paty PB, Culliford A, Romans KE, Montgomery EA, Choti MA, Kinzler KW, Vogelstein B: Counting alleles to predict recurrence of early-stage colorectal cancers. Lancet 2002;359:219-225.

207 Hugh TJ, Dillon SA, Taylor BA, Pignatelli M, Poston GJ, Kinsella AR: Cadherin-catenin expression in primary colorectal cancer: A survival analysis. Br J Cancer 1999;80:10461051.
208 Maruyama K, Ochiai A, Akimoto S, Nakamura S, Baba S, Moriya Y, Hirohashi S: Cytoplasmic beta-catenin accumulation as a predictor of hematogenous metastasis in human colorectal cancer. Oncology 2000;59:302309.

209 Ougolkov AV, Yamashita K, Mai M, Minamoto T: Oncogenic beta-catenin and MMP-7 (matrilysin) cosegregate in late-stage clinical colon cancer. Gastroenterology 2002;122:60 71.

210 Hsu HC, Jeng YM, Mao TL, Chu JS, Lai PL, Peng SY: Beta-catenin mutations are associated with a subset of low-stage hepatocellular carcinoma negative for hepatitis B virus and with favorable prognosis. Am J Pathol 2000; 157:763-770.

211 Mao TL, Chu JS, Jeng YM, Lai PL, Hsu HC: Expression of mutant nuclear beta-catenin correlates with non-invasive hepatocellular carcinoma, absence of portal vein spread, and good prognosis. J Pathol 2001;193:95-101.

212 Grabsch H, Takeno S, Noguchi T, Hommel G, Gabbert HE, Mueller W: Different patterns of beta-catenin expression in gastric carcinomas: Relationship with clinicopathological parameters and prognostic outcome. Histopathology 2001;39:141-149.

213 Nakanishi Y, Ochiai A, Akimoto S, Kato H, Watanabe H, Tachimori Y, Yamamoto S, Hirohashi S: Expression of E-cadherin, alphacatenin, beta-catenin and plakoglobin in esophageal carcinomas and its prognostic significance: Immunohistochemical analysis of 96 lesions. Oncology 1997;54:158-165.

214 Krishnadath KK, Tilanus HW, van Blankenstein M, Hop WC, Kremers ED, Dinjens WN, Bosman FT: Reduced expression of the cadherin-catenin complex in oesophageal adenocarcinoma correlates with poor prognosis. J Pathol 1997;182:331-338.

215 Shih IM, Yu J, He TC, Vogelstein B, Kinzler $\mathrm{KW}$ : The beta-catenin binding domain of adenomatous polyposis coli is sufficient for tumor suppression. Cancer Res 2000;60:16711676.

216 Roh H, Green DW, Boswell CB, Pippin JA, Drebin JA: Suppression of beta-catenin inhibits the neoplastic growth of APC-mutant colon cancer cells. Cancer Res 2001;61:65636568.

217 Chen RH, McCormick F: Selective targeting to the hyperactive beta-catenin/T-cell factor pathway in colon cancer cells. Cancer Res 2001;61:4445-4449.

218 Lipinski KS, Djeha AH, Ismail T, Mountain A, Young LS, Wrighton CJ: High-level, betacatenin/TCF-dependent transgene expression in secondary colorectal cancer tissue. Mol Ther 2001;4:365-371.

219 Korinek V, Barker N, Moerer P, van Donselaar E, Huls G, Peters PJ, Clevers H: Depletion of epithelial stem-cell compartments in the small intestine of mice lacking Tcf- 4 . Nat Genet 1998;19:379-383. 